\title{
The Role Of The Family In Educating The Character Of Elementary School Age Children In Ciseureuh Village, Purwakarta Regency
}

\author{
Imam Tabroni ${ }^{*}$, \& Misbahul Khair ${ }^{2}$ \\ ${ }^{1}$ Department of Islamic Education, STAI Dr. KH. EZ. Muttaqien, Purwakarta, Indonesia \\ ${ }^{2}$ Department of Islamic Education, STAI Dr. KH. EZ. Muttaqien, Purwakarta, Indonesia \\ DOI - http://doi.org/10.37502/IJSMR.2022.5208
}

\begin{abstract}
Character values that are instilled in the family in elementary school-aged children in the Ciseureuh village. The method of instilling character values in the family. The implications of applying this method to the character of elementary school-aged children in the Ciseureuh village. The Grand Theory Lickona Theory, Thomas. There are three components of good character proposed by Lickona Moral consciousness. Middle Theory of the Ministry of National Education and Culture. The research method used is descriptive with a qualitative approach. through interviews, observations and documentation studies. Data comes from interview scripts, field notes, photos, videos, tapes, personal documents, notes or memos, and other official documents through primary and secondary data. Data analysis techniques through data before going to the field, when in the field and processing data. so that conclusions can be drawn. The results of the research on the role of parents are to give examples, get used to, give orders, give reprimands, and give instructions. The method used by the family is the uswatun hasanah method, habituation, punishment, stories. Constraints First, some children have low self-confidence, second, some students have low motivation in the learning process, third, some students are passive in participating in learning in class, Fourth, some students are indifferent, Family support is first, becomes the basis for character building children before entering the community. second, apply the rules, regulations and discipline as appropriate. Third, being a place of refuge from disturbances that can threaten children, both threats from fellow friends and threats from outside the family. Fourth, provide provision of skills and expertise according to the talents and interests of students. Fifth, give empathy and compassion to others. Sixth, inheriting the noble values of the nation's culture. The results of the implications of applying the method are: Children are critical, Children are disciplined, Children are responsible.
\end{abstract}

Keywords: Family Role, Character Education, Elementary School Children.

\section{Introduction}

Character education is an educational process that occurs naturally and is carried out naturally and informally, in accordance with the formulation of national education goals. Character education is an educational process that occurs naturally, we can apply this in life 
before students get to know school by instilling values of character and noble character that we can apply in family life (Doni Koesoema, 2012).

The era of globalization has a negative impact on children's behavior through increasingly rapid technological developments (Harun, 2013). Indonesian student behavior such as brawls between students, free sex behavior, drug abuse, shameless culture, declining values and norms are not only found in urban areas but have penetrated into rural areas (Zuriah, 2007). School attributes such as not being able to make students educated and pay attention to ethics in behavior. This is what makes the function of education for the people of Indonesia begin to question its existence.

The first education starts from the family. The family becomes an important agent in shaping the child's personality. The implementation of Prosperous Family Development is proclaimed in the BKKBN program as stated in PP No. 21 of 1994 Article 4 paragraph (2) that: The family as the smallest unit in society consisting of husband and wife, or husband and wife and their children, or fathers and children or mothers and children in principle has eight functions, namely: (1) religious functions , (2) socio-cultural functions, (3) loving functions, (4) protecting functions, (5) reproductive functions, (6) socialization and education functions, (7) economic functions, (8) environmental development functions. Each family member has an obligation to carry out these functions so that the family can live independently and be able to develop its quality.

Character education through family functions is expected to be able to overcome the negative impacts of globalization, especially juvenile delinquency. Efforts to improve family functions and improve children's character education have been programmed by the government. Parents in carrying out family functions are influenced by cultural factors related to parenting. The pattern of parenting by parents is often passed down from their parents. Such parenting patterns are influenced by the values adopted, including the ideology in a country. The pattern of parenting in the study area strongly refers to eastern culture which highly upholds etiquette and moral values in society. A family will be considered deviant if it does not carry out family functions according to culture in society. Thus, the pattern of parenting will continue as it should be, even though the level of education, income, age, number of dependents and marital status of the family are in different conditions (Sunarti, 2012).

The importance of character education for elementary school-aged children (around the age of $6 \pm 12$ years). For this reason, children who are in primary and secondary education are the main priority for inculcating the values of good moral character. At this age is the age where at the stage of child development requires good information, relating to the formation of the child's character. With good character, it will affect the interaction of the child in society. Having a good character makes it easy to be accepted in the environment where the child is. The rules of morality in society are closely related to the good character of the community itself, including the formation of character for the children themselves. Therefore, if you want character education to be successful, its implementation must start from childhood and elementary school age children (around the age of $6 \pm 12$ years). The number of immoral actions carried out by students such as cheating, brawls, truancy and other actions indicate that formal education fails to shape the character of students (Mardiah Baginda, 2016). 
Characters that are absolutely needed are not only in the school environment, but in the social environment and also in the home environment. Even now the participants are no longer young children to teenagers, but also include adults. In this era we will be faced with competition, including colleagues in various countries in the world. Even those of us who are still working this year will definitely feel the same feeling. The demands of various quality human resources in 2021 will certainly require good character. Character is the key to an individual's success. Based on research that $80 \%$ of success for someone in society is determined by (EQ). Character education has become the center of attention in various parts of the world in order to prepare a good generation, not only for the benefit of individual citizens but for the whole community. Character education can be interpreted as our deliberate efforts from all dimensions of school/madrasah life to help build character optimally.

\section{Literature Review}

\subsection{Family Concept}

The family is a social environment that is formed closely because a group of people live, interact in the formation of mindsets, culture, and as a mediation of children's relationships with the environment. Furthermore, Latipun said that a complete and functional family can improve mental health and emotional stability of family members (Latipun, 2005). The family is also seen as an institution (institution) that can meet human (human) needs, especially the need for personality development and the development of the human race. When linking the role of the family with efforts to meet individual needs from Maslow, then the family is the first institution that can meet these needs. Through good care and treatment from parents, children can fulfill their basic needs, both physical-biological and sociopsychological. If the child has obtained a sense of security, social acceptance and self-esteem, then the child can fulfill his highest need, namely self- actualization (Syamsu Yusuf, 2012).

The role of the family in relation to early stimulation, namely the family must encourage the child's independence in doing something based on an authoritative (democratic) parenting pattern. Families must stimulate children to be interested in observing and questioning various objects or events around us, which they hear, see, feel or think about in their daily lives. The role of mothers as parents who are the closest environment is large enough to provide facilities that support the growth and development of children from an early age, and mothers have a better opportunity to modify a good environment, one of which is by stimulating growth and development according to developmental tasks for children (Rahayu, 2014).

Family education is basic education for the formation of moral development. The development of religion according to WH Clark is intertwined with elements of moral development so that it is difficult to identify clearly, because problems involving the human psyche are so complex and complex. However, through the functions of moral development which are still very simple, religion is intertwined and involved in it (Jalaluddin, 1997). So that the family also has an important role in fostering children's morals in addition to the role 
of education. Every child born has the potential to be religious, but it depends on each of the parents.

In educating their children, the role of parents is needed, to provide life provisions for the child. The school of empiricism with its famous figure John Locke (1632-1704) with its famous doctrine is "tabula rasa", a Latin term which means a blank notebook or blank sheet. This doctrine emphasizes the importance of experience, environment, and education, so that human development depends solely on the environment and educational experience (Muhibbin Syah, 2014).

Among the roles of parents towards their children (Umar, 2010), among others, first, educate them well, what is meant is about health from birth to adulthood, either in the form of food menu selection, treatment, or other preventive measures. Also by forging their bodies with beneficial exercise and righteous behavior. Second, breastfeeding, breastfeeding babies is a syar'i obligation on both parents. It is in sufficient tempo for the growth of flesh and bone strength. Third, shaving his hair in the first week of his birth, it is Sunnah to shave the hair of babies, both male and female, on the seventh day of birth and giving alms equal to the weight of his hair in silver scales to the poor . Fourth, educating their morals, what is meant by moral development is educating children to love things that are noble and high, and hate things that are low. All of this is within the framework of religious teachings and principles.

Ibn Abbas said that the Messenger of Allah said in his heart: Has told us [Al 'Abbas bin Al Walid Ad Dimasyqi] has told us [Ali bin 'Ayyash] has told us [Sa'id bin 'Umarah] has told me [Al Harith bin An Nu'man] I heard [Anas bin Malik] from the Prophet sallallaahu 'alaihi wasallam, he said: "Honor your children and correct their behavior." (HR Ibn Majah)

Fifth, educating their religion, it is the duty of parents to teach the basics of religion to their children from a young age. So, when they start learning to speak, their parents teach them the sentence of monotheism. Because the purpose of educating in Islam is ukhrawi and worldly oriented, the purpose of ukhrawi is to form a servant to carry out obligations to Allah, while the purpose of worldly is to form humans who are able to face all forms of needs and challenges of life, so that their lives are more worthy and beneficial for others.

\subsection{Character Education}

In the Poerwardarminta dictionary, character is defined as character, character, psychological traits, morals or character that distinguishes a person from others. The name of the total number of personal traits that include such things as behavior, habits, likes, dislikes, abilities, potential, values, and thought patterns (Majid \& Andayani, 2011). Character has two meanings. First, it shows how bad behavior is. Conversely, if someone behaves honestly, likes to help, of course that person manifests a noble character. Second, the term character is closely related to personality. A person can only be called a person of character if his behavior is in accordance with the moral code of a person who behaves dishonestly, cruelly or greedily, of course that person manifests (Gunawan, 2012).

According to Ibn Aḥmad al-Ghazāli in character education is needed in life to shape the character of students. In relation to moral education, it appears that character education has 
the same orientation as moral education, namely character building. The difference that moral education seems eastern and Islamic while character education seems western and secular is not a reason to be contradicted. In fact both have room to complement each other. In this case, researchers are interested in knowing about how moral education is an effort to build actual character.

David Elkind \& Sweet defines character education as follows:

"Character education is the deliberate effort to help people understand, care about, and act upon core ethical values. When we think about the kind of character we want for our children, it is clear that we want them to be able to judge what is right, care deeply about what is right, and then do what they believe to be right, even in the face of pressure from without and temptation from within".

(When we think about the kind of character we want for our children, it is very clear that they are able to judge what is truth, care deeply about truth, and then believe what is called truth, even in the face of outside pressure and efforts from outsiders. in).

As for the various characters according to the views of Western scientists (Ivan Taniputera, 2005), among others:

1) Distribution of Character According to Erich Fromm According to Erich Fromm, humans are of five kinds based on their orientation, namely:

a) Receptive Orientation. The main characteristic of people who have this character is that they always try to depend on others for support.

b) Exploitative orientation. People who have this character tend to take advantage of and manipulate others.

c) Hoarding orientation. Those who have this character tend to find security in maintaining something that has been achieved or possessed.

d) Market orientation. This character is characterized by viewing other people as objects or commodities that can be traded.

e) Productive orientation. People who have this character show the full development of human potential. Like creativity and love.

2) Character Distribution According to Otto Rank Rank divides human characters into three, namely:

a) Average. People who have this character tend to ignore their own desires and accept the wishes of the group. He believes in the truth that is believed by many people rather than his own beliefs.

b) Neurotic. People with this character tend not to conform to the wishes of the group, but also do not feel free to express their own desires and are always in conflict with society.

c) Creative. The hallmark of people who have this character is the ability to create ideas and standards for their own lives and express them to others in creative ways.

3) Character Distribution According to Karen Horney, Horney's division of character is based on a person's relationship with other people: 
a) Submissive, People who have this character, tend to have a strong need for love, approval, and acceptance of others, so that all their actions are always dependent on others.

b) Separation has a strong tendency to stay away from others because of an excessive sense of independence, so he tends to keep his distance from others.

c) Aggressive, People who have this character, tend to move against other people. He always wants to dominate others and sees life as a struggle to survive.

Zubaedi (2012) argues that there are several support factors that come from within a person that affect the success of character education as follows:

1) The Role of the Family in Character Education

Family is one of the basis of character education. The main role of character education lies in the father and mother. Children need complementary mother and father figures for character development. Education in a family will greatly affect the process of character building in society. The success of families in instilling character values in children is very dependent on the type of parenting applied by parents to their children. Through parenting by parents, children learn about many things, including character. Love and affection from parents become the main force in supporting the success of educating children's character.

2) The Role of All School Components in Character Education

In order for character education to run well, it requires sufficient and consistent understanding by all personnel and each personnel has their respective roles as follows:

a) Principals, principals as managers, must have a strong commitment to character education. The principal must be able to cultivate superior characters in his school.

b) Supervisors, even though they are not directly related to the learning process for students, they can support the success or failure of the implementation of education through the roles and functions carried out. The supervisor's role no longer only refers to the task of supervising and evaluating school administrative matters, but also as an agent or mediator of character education.

c) Educators or Teachers, Teachers are important personnel in character education in schools. Most of the interactions that occur in schools are interactions between students and teachers. Educators are figures who are expected to be able to educate children with character. Educators are role models for students and have a very big role in shaping student character.

d) Counselors, school counselors should design in their program of activities to actively participate in the development and growth of character in students. These activities can be carried out in the guidance and counseling service program, and also together with educators designed in the school program which is carried out synergistically from several parties.

e) School staff, staff or employees in the school environment are also required to play a role in character education. School staff can play a role by maintaining 
attitudes, manners, and behavior so that they can be a source of role model for students.

\section{Research Methods}

This type of research is descriptive research. This study will describe the role of the family in character education for elementary school children in Ciseureuh Purwakarta Village. Qualitative research is a particular tradition in the social sciences that is fundamentally dependent on observations of humans both in their area and in their terminology (Moeloeng, 2011).

Method is survey or interview research. Survey research is a form of descriptive research, which describes what is or is happening in the field, or in a particular area. The collected data is classified according to its type, nature, or condition. After the data is complete, conclusions are then drawn (Suharsimi Arikunto, 2010). This research was conducted to determine the role of the family on the character education of elementary school age children in Ciseureuh Village, Purwakarta Regency.

Informants in this study were conducted by purposive sampling (sampling aimed), meaning that the informants were selected based on the consideration that the selected informants or respondents had the appropriate capacity with mastery of comprehensive information about the research problem. Additional information was obtained from other informants using the snow bowling technique where the number of informants increased according to the data needed. The criteria for selecting informants as key informants in the study are individual communities or groups that have a strategic position and know the problems of family function on character education for elementary school-aged children. Respondents consist of father, mother and children. Respondents were 30 families in Ciseureuh Purwakarta Village.

Data collection can be obtained from the results of observations, interviews, documentation, and combination/triangulation. In this study, researchers used data collection techniques by means of observation, documentation, and interviews (Sugiyono, 2013). In a study, to get a valid conclusion, the validity of the data is tested on all the data collected. The data validity test was carried out using triangulation techniques that could be used to test the validity of the data, namely (1) method techniques, (2) source techniques, (3) research techniques and (4) theoretical techniques. In this study, researchers used theoretical techniques to test the validity of research data. Triangulation in this study was carried out by checking the Family Function data on Character Education of Elementary School Age Children in Ciseureuh Village, Purwakarta Regency. Triangulation of theoretical techniques is carried out as an effort to check the validity of the theoretical data.

\section{Resarch Results}

\subsection{Character Values Instilled in Children}

1) Religious

Religious values in children are not enough given through lessons, understanding, explanations and understanding. Then let the child walk alone. Instilling religious values in children requires guidance, namely efforts to guide, direct and accompany 
children in certain matters .This happened in the Ciseureh Purwakarta village, parents instilled religious values by doing congregational prayers at home with their children, even children were involved as muezzins and even priests, as stated by Zainal (parents) when praying at home always in congregation with the children, and children are actively involved. From the results of the interview, it is clear that parents in the ciseureh village of Purwakarta instill the value of religious character so that they are diligent in carrying out their obligations towards religion.

2) Care for the Environment

The attitude of love for the child's environment is the result of the educational process he experienced, both from school and parents. In general, children spend two-thirds of the day at home. Therefore, the most effective education is the example of parents. In the ciseureh village of Purwakarta, parents educate their children to care about the environment by always throwing garbage in its place, even when children do not do it, they will get a warning from their parents. Interview with ZA who lives in Bukit Soeryo Housing kel Ciseureuh Purwakarta said that "if my child littered, I immediately reprimanded him."

3) Discipline

One of the character values emphasized by parents in the Ciseureuh village is discipline, to form the discipline of children, parents make rules that are agreed with the child so that the child feels trusted and appreciated, thus the child is easy to manage and according to what has been agreed together. parent. Interview with HS at Perum Permata, Cieureuh sub-district, Purwakarta, that parents make an agreement in making rules so that children are disciplined. From the results of the interview, parents in the Ciseureuh Purwakarta village educate their children to always be disciplined when studying, playing, resting. To form this character, parents and children make agreed rules so that children feel valued so that they carry out these rules well, although sometimes laziness is a factor inhibiting children.

4) Respect Parents

Respect for parents is a good character, as a child, you should respect parents, especially for parents, especially mothers who have given birth, breast-feeding, educated to adulthood, even if their children are married, parents still help educate and care for their grandchildren. Parents in the Ciseureuh sub-district also educate their children to always respect their parents. This can be seen from the children following their parents' advice in carrying out their duties, obeying parents when forbidden and carrying out orders and rarely obeying parents. From the interview, it can be seen that parents in Ciseureuh village educate their children to respect their parents and children also respect their parents as evidenced by their obedience to the advice and rules that have been made by their parents.

5) Independent

Independence is one of the important assets for children to survive when they grow up. Therefore teaching independence is one of the most important responsibilities that parents have. Independent children will get used to doing tasks and carrying out their own obligations, although sometimes they need a warning when children forget or neglect to do their obligations. Some children in Ciseureuh village are used to 
carrying out their obligations and doing their own work. The interview with Mama Hanif said that "my son was used to doing his own work, and he also came home to play alone because he was used to it. From the results of the interview, parents in the Ciseureuh village educate their children to always do their own work so that children become accustomed to doing things without having to be asked or ordered first. Even so, because children still need guidance, sometimes feeling lazy, busy playing makes them forget their duties and obligations, so the role of parents is very important in shaping the child's independent character.

\subsection{The Method of Instilling Character Values in Children}

1) Uswatun Hasanah method

Showing exemplary is a method that must be done in shaping children's character. Educators, both parents and teachers, must show behavior that is in accordance with the advice or character attributes that the child wants to form

The example of parents and teachers is needed in shaping the child's personality so that it becomes a child with character. The purpose of Islamic education is to make every Muslim become a person who has character in accordance with the Qur'an and sunnah. If education is successfully carried out, the child will become a human being with an Islamic personality whose actions, words, knowledge and all aspects of life reflect Islamic behavior.

With thus role person old in shape character This can be done by educating children through examples of behavior. Case this because, majority person old In the village of Ciseureuh aware innate shape character child with example behavior as behavior polite polite and honor which more old very effective. Not only that, parents in Ciseureuh village too exemplify it to herself more First, so that it becomes a habit, has good behavior so that it can be imitated her children. Children will also imitate what they see more quickly on what which heard because child age 6-12 year more Imitate around especially parents. And it has been going well. Even both parents also train themselves to become a habit in life daily. Educate child through example behavior very effective in shaping children's character such as honesty, mutual honor, polite saint, fine heart, friendly, and obey the rules.

2) Habituation Method

Regarding the role of parents in shaping children's character as obey regulation religion in Ciseureuh Village, Purwakarta researcher conducted an interview with Zainal (parents) at Perum Permata which say already get used to her son in obey regulation religion, for example carrying out worship on time. But in reality child I not yet used to prayer appropriate time because factor other like lazy, especially if you've been playing with friends (Tabroni \& Juliani, 2022).

From the results of the interview above, it has been seen that parents have accustomed a child to discipline and it will be more effective if supported by refraction. Familiarize children to apply honesty, mutual respect, manners, be kind, friendly, and obey the rules so that children have good character. as a symptom of culture and social phenomena will shape the character of children for the better. Familiarizing 
children to obey religious regulations so that children can have good character is indeed very effective and has been implemented. For example: performing the five daily prayers regularly to have a good character. But sometimes other factors such as peers that sometimes make children forget to pray. However, parents in Ciseureuh Village are not tired and desperate to get used to being used to being formed into good characters (Tabroni \& Budiarti, 2021).

From the results of the interview above, parents in Ciseureuh Village direct to get used to praying on time with a habituation system that has not been effective because parents are not strict with children so that children feel underestimated. Getting used to is more emphasized and this becomes a form of habituation that will later stick and become a habit for children. However, children in Ciseureuh Village have implemented and obeyed religious regulations such as not lying and being polite to their elders. However, they have not been able to perform the five daily prayers properly and children who pray alone are not in congregation with their parents. Because parents are not firm enough to get used to praying on time according to established religious regulations.

3) Method Of Punishment

Regarding the role of parents in shaping children's character, such as discipline in the Ciseureuh Village of Purwakarta, the researcher conducted an interview with Hasan Sadikin (a parent) at Perum Dian Anyar who said that if his child made a mistake repeatedly, he would be given a punishment such as being prohibited from playing cellphones on Saturdays (Tabroni, 2019).

Punishment is needed so that children do not repeat the same mistakes. The thing that becomes the principle in giving sanctions or punishments is the stages from the lightest, moderate, to severe, because the goal is to develop the good potential that exists in children (Thomas Lickona, 1991).

From the results of the interview above, the method of punishment is applied from light ones such as being prohibited from playing cellphones to severe ones, namely confiscation of cellphones, this method is carried out so that children do not repeat and are accustomed to discipline and responsibility (Davidson \& Lickona, 2006).

4) Story Telling

Culture of dialogue between parents in Ciseureuh Village has been running. And parents can sort and choose words in dialogue or give advice, because every word that comes out of what parents say to children will be quickly caught and attached to the child's memory. Dialogue with children who are mutually enjoyable is also very necessary in the formation of children's character. Conducting a reciprocal dialogue giving advice while listening to the complaints experienced by children is very effective in shaping children's character. For example, if a child at school has difficulty doing homework. So parents help do and forbid cheating. With this, it is intended that the child and both parents can understand each other in order to form a good child's character, namely having responsibility for the tasks given. In the Ciseureuh Village, the children's character is formed with a dialogue culture, where 
the parents always help and listen to their complaints. with children or exchanging ideas, parents will have a dialogue accompanied by advice that is in accordance with the teachings of Allah SWT, has gone well with this method is also very helpful in shaping the child's character. In this way, it is hoped that the child will have a good heart in accordance with Islamic teachings. However, children feel uncomfortable with their parents to express it if they are with male parents because parents are busy working and automatically rarely have dialogue with their children.

Character education in the family environment must be really maximal and run in accordance with the government's expectations, namely to educate the nation's life and develop Indonesian people as a whole, namely humans who believe and are devoted to God Almighty and have noble character, have knowledge and skills, physical and mental health. spirituality, a strong and independent personality and a sense of social and national responsibility. Of course, this is not an easy job, therefore the family must meet several requirements, namely: (1) the family must be able to become the basis for forming the character of students before entering the community. (2) the family must be able to apply the rules, regulations and discipline as appropriate. (3) The family must be able to become a place of refuge from disturbances that can threaten the child, both threats from fellow friends and threats from outside the family. (4) Families must be able to provide skills and expertise in accordance with the talents and interests of students. (5) Families must be able to provide empathy and compassion for others. (6) The family must be able to pass down the noble values of the nation's culture. If it is done well, students when they graduate from school will be good human beings, have skills, tolerance, and can develop their talents according to their abilities. The role of the family in the formation of students' character. Parents, must treat children against children, there should be no discrimination, harsh treatment, or words that can hurt the child. The family must be an example and role model for children. Families should avoid the following things: the family teaches diligent or disciplined but the teachers themselves are often late, teaches tolerance to others but the family does not care about children, the family teaches simple life but the family itself lives in luxury, the family teaches tenderness and compassion but the teacher himself is rude to the children, the family teaches cleanliness but the family never reminds when there is garbage in the house. Those are some of the things we may still find in some families (Lickona \& Ryan, 1979).

Parental support is needed to realize the character development of students. The participation of parents in helping character formation will determine the success of students. Parents should have to believe in the school that the school is the best institution other than the family that can build the positive character of students.(Tabroni \& Purnamasari, 2022).

Families can provide counseling on how to cultivate a healthy lifestyle and foster a sense of care for the environment. Creating a clean culture, loving the environment, and not throwing trash in its place needs to be encouraged considering the character of many students who are not aware of the importance of keeping the environment clean. Moreover, students with diverse family backgrounds, of course, their habits at home must be carried over to school. Of course, this requires difficult handling from the school, especially teachers, how to change their lifestyle which has been impolite, dishonest, dirty, lazy, often late, spoiled, can turn into 
polite, honest, diligent, aware of cleanliness, independent, and being responsible certainly requires extraordinary patience.(Imam Tabroni, Erfian Syah, 2022)

Familiarizing children to pray before starting and ending lessons, praying on time, honesty can train students to be honest, grateful and obedient to worship God Almighty. Holding a ceremony every Monday to form a sense of patriotism and provide assistance to victims of natural disasters can train students to have a sense of caring for others. The key so that the cultivation of character education can be successful, of course, requires patience from parents and don't get bored to always carry out the culture that has been embedded in the school environment. Rules and regulations need to be enforced in accordance with their portions, parents must really apply the principle of " Tutwuri Handayani " so that the formation of character in schools will be realized, God willing, so that we no longer encounter students who are violent, arrogant, anarchic, and involved in crime. Of course, this is the hope of the government and society how to create future generations of gold so that they can bring this nation towards progress parallel to other developed countries in the world.

\section{Conclusion}

From the results of research on the role of parents in educating children's character in the Ciseureuh Purwakarta village, it can be concluded that the role of parents is carried out with five role person old that is giving examples, getting used to, giving orders, giving warnings, and giving instructions.

From this role, parents educate children's character by instilling character values such as religious, caring for the environment, discipline, respect for parents and discipline. results discussion there is method person old in educate character as following:

1) Uswatun hasanah method

2) Habituation method

3) Punishment method

4) Story method

\section{Acknowledgements}

An acknowledgement section may be presented after the conclusion, if desired.

\section{References}

1) Davidson, M., \& Lickona, T. (2006). Integrating Excellence and Ethics in Character Education. Social Science Docket.

2) Doni Koesoema. (2012). Pendidikan Karakter Strategi Mendidik Anak di Zaman Global. PT. Grasindo.

3) Gunawan, H. (2012). Pendidikan Karakter Konsep dan Implementasi. Alfabeta.

4) Harun, C. Z. (2013). Manajemen Pendidikan Karakter. Jurnal Pendidikan Karakter, 3, 185.

5) Imam Tabroni, Erfian Syah, S. S. (2022). Manajemen Kurikulum Pendidikan Islam Pada Masa Covid-19 di Masjid Hayatul Hasanah dan Baitut Tarbiyah Dinas 
Pendidikan Kabupaten Purwakarta. Islamic Management: Jurnal Manajemen Pendidikan Islam. DOI: Http://Dx.Doi.Org/10.30868/Im.V5i01.2141, Vol 5, No.

6) Ivan Taniputera. (2005). Psikologi Kepribadian. Ar-Ruzz Media.

7) Jalaluddin. (1997). Psikologi Agama. Raja Grafindo Persada.

8) Latipun. (2005). Psikologi Konseling. Universitas Muhammadiyah Malang.

9) Lickona, T., \& Ryan, K. (1979). Character Development in School and Beyond. Cardinal.

10) Majid, A., \& Andayani, D. (2011). Pendidikan Karakter Persepektif Islam. Remaja Rosdakarya.

11) Mardiah Baginda. (2016). Nilai-Nilai Pendidikan Berbasis Karakter Pada Pendidikan Dasar Dan Menengah. Jurnal Ilmiah Iqra', 3.

12) Moeloeng, L. J. (2011). Metodologi Penelitian Kualitatif Edisi Revisi. Remaja Rosdakarya.

13) Muhibbin Syah. (2014). Telaah Singkat Perkembangan Peserta Didik. Raja Grafindo Persada.

14) Rahayu, N. S. (2014). Hubungan Antara Karakteristik, Pengetahuan, Peran Dan Fungsi Keluarga Dengan Pemberian Stimulasi Pada Anak Usia Toddler (1-3 tahun) di Posyandu Desa Kroya Kecamatan Kroya Kabupaten Cilacap. Universitas Muhammadiyah Purwokerto.

15) Sugiyono. (2013). Metode Penelitian Pendidikan (Pendekatan Kuantitatif, Kualitatif, dan $R \& D$ ) (16th ed.). CV Alfabeta.

16) Suharsimi Arikunto. (2010). Prosedur Penelitian Suatu Pendekatan Praktik. Rineka Cipta.

17) Sunarti, E. (2012). Pengaruh Perubahan Sosial terhadap Keluarga. Jurnal Sosial Individu, Keluarga, Dan Masyarakat, 1 .

18) Syamsu Yusuf. (2012). Psikologi Perkembangan Anak dan Remaja. Remaja Rosdakarya.

19) Tabroni, I. (2019). MODEL PENDIDIKAN ISLAM: Teknik Mendidik Anak dengan Treatment di Era 4.0. CV Cendekia Press.

20) Tabroni, I., \& Budiarti, D. (2021). PERAN KYAI DALAM MEMBINA AKHLAK SANTRI DI PONDOK PESANTREN AL-MUINAH DARUL ULUM DESA SIMPANG KECAMATAN WANAYASA. Jurnal Pendidikan, Sains Sosial, Dan Agama, 7(2), 108-114.

21) Tabroni, I., \& Juliani, A. (2022). PERAN ORANG TUA DALAM MEMBINA AKHLAK ANAK PADA MASA PANDEMI DI RT 64 GANG MAWAR IV PURWAKARTA. Jurnal Sosial Humaniora Dan Pendidikan, 1(1 SE-Articles). http://ejurnal.stie-trianandra.ac.id/index.php/inovasi/article/view/172

22) Tabroni, I., \& Purnamasari, R. (2022). Kajian Yasinan Mingguan dalam Membina Karakter Masyarakat Pada Masa Covid-19 di Perumahan Lebak Kinasih Purwakarta. Sivitas: Jurnal Pengabdian Dan Pemberdayaan Masyarakat, 2(1), 9-18. https://doi.org/10.52593/svs.02.1.02

23) Thomas Lickona. (1991). Educating for Character: How Our Schools Can Teach Respect and Responsibility. Bantam Books.

24) Umar, B. (2010). Ilmu Pendidikan Islam. Amzah. 
108 | International Journal of Scientific and Management Research 5(2) 87-94

25) Zubaedi. (2012). Desain Pendidikan Karakter (2nd ed.). Kencana Prenada Media Group.

26) Zuriah, N. (2007). Pendidikan Moral dan Budi Pekerti dalam Perspektif Perubahan Mengagas platform Pendidikan Budi Pekerti secara Kontekstual dan Futuristik. Bumi Aksara. 